\title{
Distance Learning - A Potential Opportunity for Thailand
}

\author{
Nachayapat Rodprayoon ${ }^{1}$, Chompu Nuangjamnon ${ }^{2} \&$ Stanislaw Paul Maj. ${ }^{3}$ \\ ${ }^{1}$ Faculty of Business Administration, Rajamangla University of Technology, Thanyaburi, Pathumthani, Thailand \\ ${ }^{2}$ Faculty of Business Administration, Saint John's University, Bangkok, Thailand \\ ${ }^{3}$ Engineering Institute of Technology, Western Australia \\ Correspondence: Dr S P Maj, Associate Dean (Research), Engineering Institute of Technology, 1031 Wellington \\ St., West Perth, 6005, Western Australia. Tel: 1-300-138-522. E-mail: paulm@eit.edu.au
}

Received: May 30, 2017

doi:10.5539/mas.v11n11p20
Accepted: June 15, 2017

Online Published: October 21, 2017

URL: https://doi.org/10.5539/mas.v11n11p20

\begin{abstract}
Distance learning is a global phenomenon with a wide range of available courses; however concerns exist regarding both course quality and educational standards. Within Australia the further and higher education sectors are highly regulated by the Tertiary Education Quality and Standards Agency and the Australian Skills Quality Authority respectively. All educational providers must meet the appropriate compliance requirements. The Open Universities Australia consortium is a group of eight Australian Universities. This consortium offers 44 undergraduate awards and 127 postgraduate awards; however they are predominantly in disciplines suitable for distance learning. The Engineering Institute of Technology offers a wide range of accredited distance learning courses but to people already in the workforce. Despite the widespread availability of eLearning tools such as mobile learning and well established instructional platforms within Thailand Online Distance Learning (ODL) is not well represented. In order to analyze potential barriers to this mode of learning a group of Thai university students attended a 1.5 hour lecture remotely and feedback was collected. The results clearly demonstrate that within this single cohort there was considerable interest in studying in a distance learning mode.
\end{abstract}

Keywords: distance learning, on-line learning, remote education

\section{Introduction}

\subsection{Introduce the Problem}

Distance learning is the educational deployment mode in which students never physically meet their lecturers. The continuing improvements in communications technologies provide a platform that is not only reliable but also supportive of progressively higher bandwidths capable of allowing the transmission of high quality video ("National Broadband Netowrk," 2017). There are numerous advantages to distance learning but a principle one is as convenience i.e. the opportunity to study any time, any place. However there have been concerns regarding course quality and educational standards. According to Morrison with the USA, The view that online education is "just as good as" face-to-face instruction was not widely held in 2003: 42.8\% of chief academic officers reported that they considered the learning outcomes for online instruction to be inferior to face-to-face instruction. (Morrison, 2015). Reasons cited by Morrison include the lack of authoritative body to address minimum levels of standards.

Within Australia the further and higher education sectors are regulated by the Tertiary Education Quality and Standards Agency (TEQAS) and the Australian Skills Quality Authority (ASQA) respectively. TEQSA's legislative objectives include the assurance of national consistency and use of a standards-based quality framework. In 2017 TEQSA introduce a new quality framework consisting of seven domains (student participation \& attainment; learning environment; research and research training; institutional quality assurance; governance and accountability; representation, information and information management) (Agency, 2017). All educational providers must meet the appropriate compliance requirements. Distance learning is an established method of delivery in Australia. In support of this mode of delivery there exists the Open Universities consortium established by eight universities - Curtin, Griffith, La Trobe, Macquarie, Murdoch, RMIT, Swinburne and the University of South Australia. It is possible to study at undergraduate or postgraduate level in seven discipline areas: Arts \& Humanities, Business, Education, Health, Information Technology, Law \& Justice, and Science \& Engineering. There are a comprehensive range of awards. Furthermore it is possible to study 
either an entire course or individual units. There are forty four undergraduate awards (table 1) and 127 postgraduate awards (table 2).

Table 1. Undergraduate awards

\begin{tabular}{ll}
\hline Discipline & Number of undergraduate courses \\
\hline Arts \& Humanities & 22 \\
Business & 6 \\
Education & 2 \\
Health & 2 \\
Information Technology & 4 \\
Law \& Justice & 3 \\
Science \& Engineering & 5 \\
\hline
\end{tabular}

Table 2. Postgraduate awards

\begin{tabular}{ll}
\hline Discipline & Number of undergraduate courses \\
\hline Arts \& Humanities & 29 \\
Business & 37 \\
Education & 11 \\
Health & 13 \\
Information Technology & 6 \\
Law \& Justice & 13 \\
Science \& Engineering & 18 \\
\hline
\end{tabular}

In the case of one undergraduate award - Bachelor of Business Information Systems, the course overview is as follow:

The course emphasis is on the effective use of information and information technology within an organization and the development of systems for solving business problems. The Bachelor of Business Information Systems aims to create information systems (IS) professionals who add value to the organization by having both a strong technical background and the ability to liaise with team members and other stakeholders including clients. The degree incorporates a breadth of knowledge around the technology fundamentals including programming, databases, networking and web design. An appreciation of the overall architecture of information systems and design issues around human-computer interaction, information risk and security, business information systems strategy, project management, and process modelling are an integral part of the course. The growing demand for IS professionals who can provide IS/IT expertise while showing an aptitude towards the organizational environment and the ability to communicate with the business users, means that graduates of this degree can enjoy career opportunities where IS/IT requisite skills and knowledge are highly valued. The course also provides individuals with the requisite academic knowledge and skills to undertake further learning at higher levels such as Honours, Graduate Certificate, or Masters (by coursework) within the field of IS/IT and/or an area closely related to IS/IT.

This overview indicates a comprehensive course structure indistinguishable from a traditional face to face delivery mode. However it should be noted that the courses offered by Open Universities are predominantly in disciplines suitable for distance learning. In a blended learning mode there is a combination of lecturing online but where students experience face to face instruction at some point during their studies. Practical subjects such as engineering require students to obtain practical hands on skills which would be acquired during this face to face component. Hence the Associate Degree in Engineering offered by the University of South Australia (Open Universities) requires students to attend laboratory classes in block mode. This is a mandatory requirement. An alternative approach is taken by the Engineering Institute of Technology EIT). EIT offers a wide range of accredited distance learning courses but to people already in the workforce. Arguably therefore it is possible to provide a quality assured learning pathway by means of distance or blended learning. However within Thailand distance learning is not well represented.

\subsection{Online Distance Learning in Thailand}

Quality and equity in education are key principles of the Ministry of Education in Thailand, 
Quality student-centered education is provided for everyone with distribution of equitable education opportunities, in cities, rural and outreached areas. Education leads to people's vigour building. Vigourous and knowledgeable people are powerful capital to fight poverty. ("Ministry of Education Thailand. Ministry profile: vision and mission," 2010). The importance of online distance education (ODL) as a means to deliver this strategic objective is recognized. Five critical factors to the success of ODL were identified, namely: institutional management, learning environment, instructional design, services support and course evaluation (Cheawjindakarn, 2012). From a pedagogical perspective the key factors are both instructional design and the learning environment. For successful teaching and learning outcomes in an ODL delivery mode, Cheawjindakarn identified five elements in instructional design (clarification of objectives, content quality, learning strategies, psychology of learning and learning assessment and four elements in learning environment (course management system, technical infrastructure, interactive learning and also access and navigation. In the case of learning environment specific mention is made of the need for sufficient bandwidth for downloading and system reliability. Regarding content quality mention is made of the need for a strong pedagogical foundation. ODL is of potential value not only to students resident in cities but especially for students in rural and remote areas (Pacific, 2001). However teaching and learning styles are culturally dependent and should be taken into account in an ODL delivery mode (Srichanyachon). Despite the potential of ODL the success rate is low (Tanchaisak). Tanchaisak identified significant concerns regarding the quality of ODL, namely: lack of learning and support facilities, lack of group work, minimal interactions in learning and sharing and infrastructure. The importance of recognizing that the Asian modes of learning differ from the Western style was highlighted. According to Tanchaisak, However, the nature of distance learning is different from the traditional approach. Asian students were mostly not constructivists. While the distance learning program students should construct knowledge facilitated by instructors, students in Thailand were more traditional, i.e. rather passive. The teaching style might not correspond to the preferred learning styles. In general, their learning preference at tertiary level could be predicated on the way they had been learning earlier in the past (primary and secondary schools and even colleges). Rote learning had been ingrained in them and indeed their teachers and lecturers that the whole system was predominantly rote learning. A blended learning approach, as opposed to ODL, is well represented in Thailand (Wattanapanit). Clearly there are challenges to the more extensive use of ODL in Thailand. This paper focuses primarily on evaluating the use of an interactive style of teaching in an ODL environment. Challenges to be considered include: cultural expectations, limited knowledge of English (lecture to be in English)

\section{Method}

Thirty second year Thai students enrolled on a Business Computer degree program were taught for approximately one and a half hours entirely in distance learning mode. The power point slides were provided to the students in advance. These power point slides consisted of lecture material; partially completed tables and questions to be considered. It should be noted that the material supplied was extracted from award winning lecture material. There are different distance learning platforms; in this case the one used was Blackboard. The Blackboard interface provides different panes - audio \& video; participants, chat and lecture material. It is possible to see which students are online and interact with students with by chat or voice. Interaction is facilitated by the use of icons which are a quick and simple method of communication e.g. speed up, slow down etc.

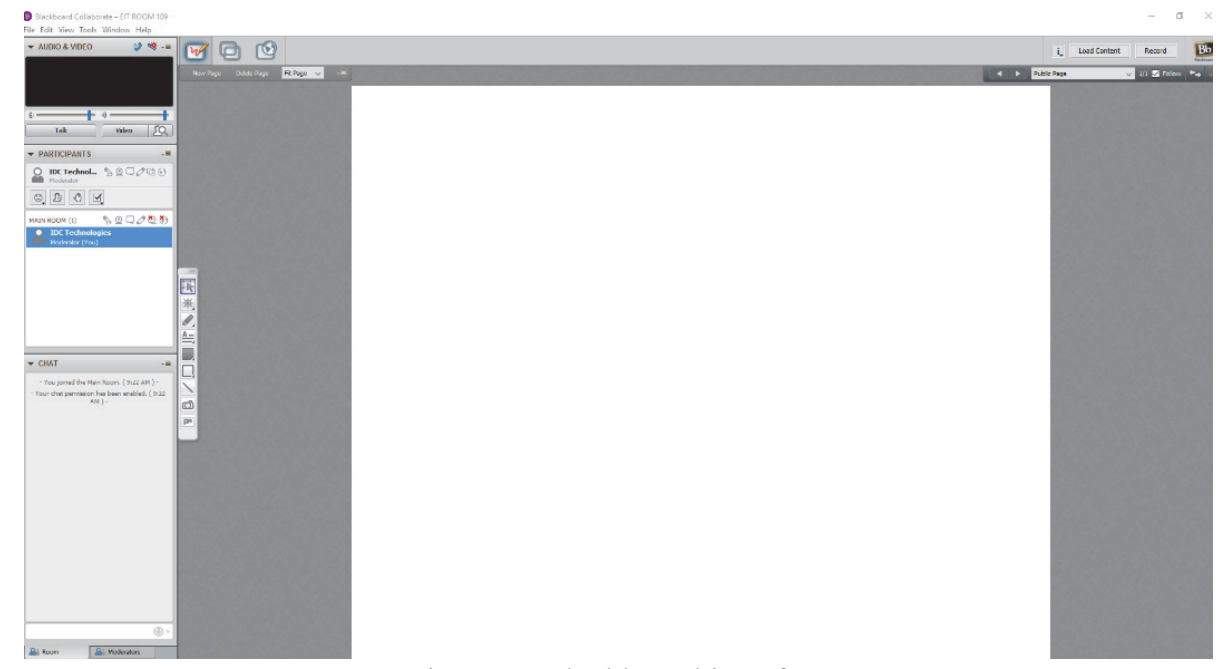

Figure 1. Blackboard interface 


\section{Results}

The teaching method employed was substantially interactive with frequent questions to the entire group and also to specific individuals in order to determine the level of understanding. However voluntary responses to the entire group were predominantly from about one third of the students. During the lecture it became apparent a number of students were hesitant as they were not confident in their English language ability.

The first part of the questionnaire was to determine what students thought about the quality of the lecture material, delivery and interactivity. To provide quantitative data Likert scales were used along with the option to provide individual comments. The questionnaire was voluntary and anonymous.

1. On a scale of 1 to 5 how would you rank the quality of the lecture material?

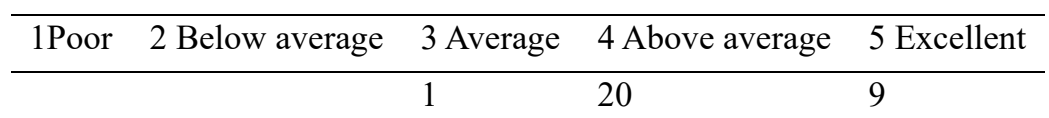

- The professors explained well, but I'm not good in English, but still enough to understand the description lol.

- Has added English teaching.

- Excellent because it is a quality and easy to use.

- There is a wide range of teaching.

- Dr.Pual he teach very well and make student understand.

- The content covers very well. I like the content you bring.

- Content is easy to understand. Interesting video

- There is wide range of teaching

- I think well

2. On a scale of 1 to 5 how would you rank the quality of the delivery?

\begin{tabular}{|c|c|c|c|c|}
\hline 1Poor & 2 Below average & 3 Average & 4 Above average & 5 Excellent \\
\hline & & 6 & 22 & 2 \\
\hline
\end{tabular}

- Has added English teaching.

- Promise to say good but video signal stumbles and slows.

- A picture not clear

- My internet is so bad

- There are a few crashes. But overall everything fine

- I think well

3. The lecture was designed to be interactive. On a scale of 1 to 5 how would you rank this interactive approach?

\begin{tabular}{|c|c|c|c|c|}
\hline 1Poor & 2 Below average & 3 Average & 4 Above average & 5 Excellent \\
\hline & & 6 & 10 & 14 \\
\hline
\end{tabular}

- I want to teach slower and more time more.

- Have a good retaliation for the listener.

- Explain easily. Not confused and make more knowledge

- Interesting excellent

- I think lecture excellent

Learning by online delivery has advantages and disadvantages. 
4. What do think the advantages are?

- The knowledge gained is very useful. An additional special education classes.

- Learning online or Internet is easy, convenient, easy to find.

- Can answer questions understand.

- It easy to learning everything.

- Interesting to study.

- Can exchange knowledge and convenient

- It is convenient learning. Can exchange knowledge well. Do not waste money

- Modern and interesting.

- Review later knowledge.

- Fun to learn.

- - Make teaching comfortable.

- The advantages of this modern, fast-paced, And communication between Instructor with student

- Offer something clear.

- Students can interact with the teacher. And immediately ask questions to the teacher immediately.

- I'm understrand your talk about it

- Online study makes it convenient. No matter where you are I can study or access knowledge content

- Material is high technology. I love it.

- Can study on line. Do not have to travel far Where I can learn

- It is convenient to study

- It is good

- Easy to learn

- Convenient and can be accessed anywhere

- Easy to study

- = help review

- =It's fun

- Interested in learning and exchanging languages

- I enjoy teaching and interacting and easy to understand

- The development in education is universal

- Have fun learning. And easy to understand

- Listen to authentic Australian accents

- Thank for teach

- Fun to learn, very interesting. Happy

- Easy to understand and very useful learning

- Our teachers teach us even though we understand a little English

5. What do you think the disadvantages are?

- The Internet signal from my country, it was very slow to slow

- Online learning, it makes us no if yes, in the wrong way.

- Internet signal is not good.

- Maybe internet is not good make me don't understand something.

- The signal is not good

- The signal is unstable. 
- Understanding between learner and instructor This may be due to language differences.

- Teaching a variety.

- easy to understand

- Content covered

- Feel fun to study

- Hurry

- The signal is not good.

- The disadvantage is that the signal is rarely convenient. To communicate This should be improved.

- Unstable

- Online learning if the Internet is not good will not understand. And missed school

- Internet delay

- Sometimes the internet has problems. The lack of continuous communication

- Each internet can have different speeds. Make the communication inaccurate

- Noise from the keyboard

- Understanding between the learner and the instructor. Because the students may have skills. The language is not good.

- The video image is not clear

- The signal is not clear

- Do not see each other

- =Can not watch video

- =I'm weak English

- The signal is not good

- Signal not connected

- Blurred signal

- I have to have other subjects as well (sample subject Databases Because it's too hard)

- The signal is unstable

- None

- I think don't have disadvantages

- My computer has a problem downloading the program and I learn with my friend

6. If you were given the choice to study a unit online, on a scale of 1 to 5 what would your preference be?

\begin{tabular}{lllll}
\hline $\begin{array}{l}\text { 1Definitely not } \\
\text { interested }\end{array}$ & $\begin{array}{l}\text { 2 Probably not } \\
\text { interested }\end{array}$ & $\begin{array}{l}3 \text { No } \\
\text { preference }\end{array}$ & $\begin{array}{l}4 \text { Possibly } \\
\text { interested }\end{array}$ & $\begin{array}{l}5 \text { Definitely } \\
\text { interested }\end{array}$ \\
\hline & & 2 & 23 & 3 \\
\hline
\end{tabular}

- Because the Internet in Thailand is still delayed.

- It is convenient learning. Can exchange knowledge well. Do not waste money

- Want to learn more.

- I want it to be my language. I will listen to easy to understand. I like the content you tell

- Thank you for today Dr.Pual

For the first question (quality of lecture material) 29 students rated the material above average or excellent. The comments are supportive of this but there was some concern over their English language ability. The second question (quality of delivery) on reflection was ambiguous. The intention was to evaluate the pedagogy 
regarding pace, tone of voice, distribution of attention amongst students etc. The responses were an evaluation of the quality of the on-line medium of delivery. Despite comments about problems with the technology 29 students rated the delivery above average or excellent. For the third question (quality of lecturer student interaction) 24 students gave a score of above average or excellent. Four of the five student comments regarded the interaction of excellent. There are different methods of distance learning delivery. One method is to provide students with pre-recorded webinars complemented by real-time lectures which are also recorded. This was the preamble on the questionnaire to allow the students to understand how distance learning is deployed. Regarding the advantages of distance learning there were a substantial number of positive responses. Regarding potential disadvantages student comments highlighted the problems associated with poor quality internet connections resulting in: delays, signal drop out, noise etc. Significantly one student comment was 'Do not see each other'. Finally 26 students responded that they would possibly or definitely be interested in studying a unit on-line. IN addition to this qualitative analysis the results were statistically analyzed (table 1) - the mean values were high for all the pedagogical issues. However evaluations for the language barrier were below average.

Table 3. Statistical analysis of results

\begin{tabular}{|c|c|c|c|c|c|c|c|c|}
\hline The satisfaction of distance learning & Excellent & $\begin{array}{l}\text { Above } \\
\text { average }\end{array}$ & Average & $\begin{array}{l}\text { Below } \\
\text { average }\end{array}$ & Poor & Total & Mean & Evaluation \\
\hline \multicolumn{9}{|l|}{ Application of Distance Learning } \\
\hline 1 Interesting & 29 & 6 & 0 & 0 & 0 & 35 & 4.83 & Excellent \\
\hline 2 Easy to use & 4 & 12 & 15 & 4 & 0 & 35 & 3.46 & Above average \\
\hline 3 Flexibility & 5 & 14 & 12 & 4 & 0 & 35 & 3.57 & Above average \\
\hline $\begin{array}{l}4 \text { The quick response through Internet } \\
\text { Web browser }\end{array}$ & 2 & 8 & 18 & 7 & 0 & 35 & 3.14 & Average \\
\hline $\begin{array}{l}5 \text { Having the channel for student to } \\
\text { question - answer with the lecturer }\end{array}$ & 12 & 20 & 3 & 0 & 0 & 35 & 4.26 & Above average \\
\hline \multicolumn{9}{|l|}{ Content in Computer Networking Unit } \\
\hline $\begin{array}{l}6 \text { Lecturer focus on the objective of } \\
\text { teaching }\end{array}$ & 25 & 10 & 0 & 0 & 0 & 35 & 4.71 & Excellent \\
\hline 7 The contents for learner is suitable & 15 & 10 & 5 & 5 & 0 & 35 & 4.00 & Above average \\
\hline 8 Language Problem & 0 & 6 & 8 & 10 & 4 & 28 & 2.06 & Below average \\
\hline 9 Time & 22 & 9 & 4 & 0 & 0 & 35 & 4.51 & Excellent \\
\hline 10 Motivation of learner & 16 & 12 & 5 & 2 & 0 & 35 & 4.20 & Above average \\
\hline
\end{tabular}

\section{Discussion}

There are considerable potential advantages to Online Distance Learning (ODL). This is especially the case for students located in rural and remote locations making idea for developing countries such as Thailand. However, it is recognized that ODL is not well represented in Thailand which may be due to different factors such as learning styles based on cultural expectation. In this experiment students were taught based on award winning lecture material that required a highly interactive teaching and learning style. Despite this the lecture was highly regarded by students who recognized the potential of ODL. However ODL is entirely dependent of the supporting infrastructure that must have sufficient bandwidth and reliability.

\section{References}

Agency, T. E. Q. A. S. (2017). TEQSA contextual overview of the new HES Framework. Retrieved from http://www.teqsa.gov.au/teqsa-contextual-overview-hes-framework

Cheawjindakarn, B., Suwannatthachote, P., \& Theeraroungchaisri, A. (2012). Critical Success Factors for Online Distance Learning in Higher Education: A Review of Literature. Creative Education, 3, 61-66.

China Agricultural Broadcasting and Television School (CABTS) (2001). Expert Consultation on Rural Women and distance learning: regional strategies. Food and Agriculture Organization of the United Nations 
Regional Office for Asia and the Pacific, Bangkok.

Ministry of Education Thailand. Ministry profile: Vision and mission. (2010). Retrieved from http://www.en.moe.go.th/index.php?option=com_content\&view=article\&id=19\&Itemid=54

Morrison, D. (2015). How 'Good' is Your Online Course? Five Steps to Assess Course Quality. Retrieved from https://onlinelearninginsights.wordpress.com/2015/05/26/how-good-is-your-online-course-five-steps-to-ass ess-course-quality/

National Broadband Netowrk. (2017, May 2017). Retrieved from https://en.wikipedia.org/wiki/National_Broadband_Network

Srichanyachon, N. (2010). Key Components of E-Learning Readiness. Retrieved from http://www.bu.ac.th/knowledgecenter/epaper/jan_june2010/pdf/Page_56.pdf

Tanchaisak, K. (2015). The Management of International Online Distance Learning Program in Thailand. Retrieved

from

file://D:/JULY-2015/Research/MAS/Thai\%20paper/The\%20Management\%20of\%20the\%20International\% 20Online\%20Distance\%20Learning\%20TH.pdf

Wattanapanit, N. (2015). The Students' Perceptions toward Ramkhamhaeng University Blended Distance Learning. $\quad$ Retrieved from file://D:/JULY-2015/Research/MAS/Thai\%20paper/The\%20Students\%20Perceptions\%20toward\%20Ram khamhaeng\%20University.pdf

\section{Copyrights}

Copyright for this article is retained by the author(s), with first publication rights granted to the journal.

This is an open-access article distributed under the terms and conditions of the Creative Commons Attribution license (http://creativecommons.org/licenses/by/4.0/). 